\title{
Prolonged exposure of pancreatic islets isolated from "pre-diabetic" non-obese diabetic mice to a high glucose concentration does not impair Beta-cell function
}

\author{
D.L.Eizirik, E. Strandell and S. Sandler \\ Department of Medical Cell Biology, Uppsala University, Uppsala, Sweden
}

\begin{abstract}
Summary. In the early stages of Type 1 (insulin-dependent) diabetes mellitus patients present a deficient insulin response to glucose. The reasons for this defective response are unknown, but it has been suggested that it reflects a deleterious effect of excessive glucose stimulation on a reduced Beta-cell mass. Female non-obese diabetic (NOD) mice from our colony, at the age of 12-13 weeks, have a normal basal glycaemia but an impaired intravenous glucose tolerance test, insulitis and a defective insulin response to glucose. In order to characterize the potential effect of glucose on the Beta cells at that "pre-diabetic" stage, pancreatic islets were isolated from 12-13 week old female NOD mice. Immediately after isolation (day 0) the NOD islets displayed a defective insulin response to an acute stimulation with $16.7 \mathrm{mmol} / 1$ glucose. After seven days in culture at botb 11 and $28 \mathrm{mmol} / \mathrm{l}$ glucose these islets showed an increased insulin release in response to an acute glucose stimulation. This increase was more pronounced in the islets cultured at $28 \mathrm{mmol} / \mathrm{l}$ glucose. Experi-
\end{abstract}

ments performed in parallel, using islets obtained from a non-diabetes prone strain of mice (Naval Medical Research Institute, NMRI) showed that these islets had a similar insulin release in response to glucose both on day 0 and after seven days in culture at $11 \mathrm{mmol} / 1$ glucose. The insulin mRNA levels of NOD islets did not change over one week in culture at 11 or $28 \mathrm{mmol} / \mathrm{lglucose}$, but culture at the high glucose concentration induced a decrease in the islet insulin content. The present data show that culture at high glucose concentrations does not impair the function of islets isolated from NOD mice. These observations make excessive glucose stimulation, as a single factor, an unlikely explanation for the defective insulin release observed in NOD islets in the "prediabetic" period.

Key words: Glucose, Type 1 (insulin-dependent) diabetes mellitus, insulin release, NOD mice, pancreatic islets, tissue culture.
There is much evidence to suggest that the clinical onset of Type 1 (insulin-dependent) diabetes mellitus is preceded by a long-lasting autoimmune assault to the pancreatic Beta cells [1]. In parallel with the decrease in the Beta-cell mass, the patients present with an increasingly defective insulin response to $\dot{i}$. v. glucose, while they are still able to release insulin in response to non-nutrient secretagogues [2]. The reasons for this defective response to glucose remain unclear, but it has been suggested that this finding reflects a deleterious effect of excessive glucose stimulation on a reduced Beta-cell mass $[3,4]$. The further clarification of these issues has been hampered by difficulties in dissociating the effects of toxic and/or immunologically mediated Beta-cell injury from that of the progressive hyperglycaemia, inherent to in vivo models of insulin-dependent diabetes mellitus.

The non-obese diabetic (NOD) mouse currently represents one of the best animal models of human Type 1 diabetes mellitus $[5,6]$. The onset of hyperglycemia in these mice is preceded for several weeks by insulitis and ongoing Beta-cell destruction. During this "pre-diabetic" period the NOD mouse develops a progressively impaired glucose tolerance, and their Beta cells show a defective insulin response to glucose, coupled with higher response to arginine and theophylline [7, 8]. Thus, this "pre-diabetic" phase of the NOD mouse represents a goodexperimental model in which to study the putative deleterious effects of excessive glucose stimulation of the islets of Langerhans during the early phases of insulin-dependent diabetes mellitus.

In the present study, pancreatic islets were obtained from 12-13 week old female NOD mice, an age at which most female animals of our NOD mice colony already exhibit glucose intolerance, insulitis and an impaired islet insulin response to glucose in vitro [8]. The Beta-cell function was evaluated immediately after islet isolation or after one week in tissue culture at 11.1 or $28 \mathrm{mmol} / \mathrm{glu}$ cose, by the measurement of glucose-stimulated insulin 
release, the number of islets retrieved after culture, and the islet DNA, insulin and insulin mRNA contents. As a control, designed to assess the impact of the culture condition alone on the islets, pancreatic islets from non-diabetic prone Naval Medical Research Institute (NMRI) mice were also studied.

\section{Materials and methods}

\section{Animals}

Female NOD mice, aged 12-13 weeks, were used in the experiments. The NOD mouse colony was established in Uppsala in March 1988, by brother and sister mating of the offsprings from three breeding pairs of inbred NOD mice obtained from the Clea Company (Aobadi, Japan). The cumulative incidence of diabetes in the colony at 28 weeks of age is $47 \%$ for the females and $7 \%$ for the males. On the day preceding the islet isolation (see below), a blood sample was obtained in non-fasting animals by retroorbital puncture and the serum glucose concentration was analysed using an automated glucose oxidase method (Glucose Analyser 2, Beckman Instruments, Fullerton, Calif., USA).

As an external control, designed to test the possibility that islet adaptation to a culture condition could by itself influence the results, islets from male NMRI mice (Anticimex AB, Sollentuna, Sweden) were also studied. NMRI mice are a non-diabetes prone strain of mice, not related to the NOD mice and without any known autoimmune disease. Islets from male NMRI mice has been extensively studied in our laboratory as regards islet metabolism and function. In some experiments (Table 3), islets obtained from female NMRI mice were also studied.

\section{Morphology, islet isolation and culture}

Non-fasted female NOD or male NMRI mice were killed by cervical dislocation and the pancreas was quickly removed. A piece of the pancreas (about $10-20 \%$ of the pancreatic mass) was fixed in Bouin's solution for light microscopical examination and the remaining material utilized for islet isolation (see below). The sections (at least 60 consecutive sections, $7 \mu \mathrm{m}$ thick) were stained with haematoxylin and eosin and ranked in four classes for the presence of inflammatory cells, as previously described [9]. Class A denotes normal islet morphology; class B denotes a low degree of mononuclear cell infiltration especially in the periinsular area; class C denotes a heavy cell infiltration into a majority of islets and class $\mathrm{D}$ denotes that only a few residual islets could be identified, exhibiting an altered islet architecture and signs of cell degeneration.

Pancreatic islets were isolated by collagenase digestion [10] and hand-picked. By this method it was possible to obtain approximately 80 islets from each individual NOD mouse. A similar number of islets were picked from the NMRI mice. The islets were either immediately used for experiments (day 0 ) or cultured free-floating for seven days (day 7) in culture medium RPMI 1640 (Flow Laboratories, Irvine, UK) containing 11.1 or $28 \mathrm{mmol} / \mathrm{l}$ glucose and supplemented with $10 \%$ donor calf serum (Flow), benzylpenicillin $(100 \mathrm{U} / \mathrm{ml})$ and streptomycin $(0.1 \mathrm{mg} / \mathrm{ml})$ [11]. The culture medium was changed every second day, and samples of the medium frozen at $-20^{\circ} \mathrm{C}$ for subsequent determination of insulin accumulation by radioimmunoassay [12]. On the last day of culture, the islets were recounted under a stereomicroscope, and the number of remaining islets expressed as a percentage of the islet number on day 0 . Some of the cultured islets were fixed in Bouin's solution, paraffin embedded, sectioned and stained with haematoxylin-eosin.

\section{Islet insulin release, $D N A$, insulin and} insulin $m R N A$ contents

For the insulin release experiments, the islets were divided into triplicate groups of seven islets each and placed in sealed glass vials containing $0.25 \mathrm{ml}$ bicarbonate buffer [13] supplemented with $10 \mathrm{mmol} / \mathrm{h} \mathrm{HEPES}$ and $2 \mathrm{mg} / \mathrm{ml}$ albumin (KRBH buffer). During the first hour of incubation at $37^{\circ} \mathrm{C}\left(\mathrm{O}_{2}: \mathrm{CO}_{2} ; 95: 5\right)$ the $\mathrm{KRBH}$ medium contained $1.7 \mathrm{mmol} / \mathrm{l}$ glucose. The medium was then gently removed and replaced by $0.25 \mathrm{ml} \mathrm{KRBH}$ supplemented with $16.7 \mathrm{mmol} / 1$ glucose, followed by incubation for a second hour. The insulin concentration in the incubation medium was determined by radioimmunoassay [12]. In each experimental group the insulin secretion was calculated as a mean of the values obtained from the three incubation vials. After the insulin release experiments, the islets were pooled and disrupted by sonication in $0.2 \mathrm{ml}$ redistilled water. A $50 \mu \mathrm{l}$ aliquot of the aqueous homogenate was mixed with $125 \mu \mathrm{l}$ acid ethanol and the insulin extracted overnight at $4^{\circ} \mathrm{C}$. DNA was measured fluorophotometrically in another fraction of the water homogenate $[14,15]$.

In order to obtain a sufficient number of islets for the insulin mRNA quantification on days 0 and 7, the pancreata of two NOD or two NMRI mice were pooled in each group, and the islets isolated as described above. Groups of 50 islets were sonicated and RNA extracted with phenol-chloroform. Insulin mRNA was quantified by dot blot analysis [16, 17], as previously described [18]. The probe for hybridization was pRI-7 [19]. After hybridization, the filters were washed and then exposed at $-70^{\circ} \mathrm{C}$ to Hyperfilm-MP (Amersham International, Amersham, UK) with an intensifying screen. The intensities of the spots thus obtained were determined by densitometry.

\section{Statistical analysis}

Means \pm SEM were calculated. The data were then analysed by analysis of variance, followed by multiple comparisons using the Student's paired $t$-test. The $p$-values were corrected for multiple comparisons using the Bonferroni method [20].

\section{Results}

The 12-13 week old NOD mice included in the study were not overtly diabetic. The observed serum glucose concentrations were $7.9 \pm 0.9 \mathrm{mmol} / \mathrm{l}$ in the NOD mice $(n=8)$ and $10.0 \pm 0.7 \mathrm{mmol} / 1$ in the NMRI mice $(n=7)$. Light microscopic examination of the pancreatic sections showed that all NMRI mice belonged to class A (normal islet morphology) $(n=9)$. In contrast, all NOD mice $(n=10)$ had some degree of mononuclear cell infiltration, with three animals ranked as class B and the remaining seven mice as class $\mathbf{C}$.

The loss of islets after the seven-day culture period was less than $10 \%$ in all groups (Table 1 ). On day 0 the NOD islets had high DNA contents. This finding is probably explained by the contribution of infiltrating mononuclear cells to the total DNA content, as previously described [8]. After seven days in culture these mononuclear cells tend to disappear [8], and the NOD islets attain a similar DNA content as that of the NMRI islets. Exposure to a high glucose concentration in culture did not modify the islet retrieval or the DNA content of the islets obtained from both NOD or NMRI mice. Furthermore, light microscopical examination of NOD or NMRI 
Table 1. Islet recovery, DNA content and insulin and insulin mRNA contents of islets isolated from NOD or NMRI mice and studied immediately or after seven days in culture at different glucose concentrations

\begin{tabular}{|c|c|c|c|c|c|c|}
\hline \multirow[t]{2}{*}{ Mouse strain } & \multirow{2}{*}{$\begin{array}{l}\text { Medium glucose } \\
(\mathrm{mmol} / \mathrm{l})\end{array}$} & \multirow{2}{*}{$\begin{array}{l}\text { Islet retrieval } \\
(\%)\end{array}$} & \multirow{2}{*}{$\begin{array}{l}\text { DNA content } \\
\text { (ng/10 islets) }\end{array}$} & \multicolumn{2}{|c|}{ Insulin content } & \multirow{2}{*}{$\begin{array}{l}\text { Insulin mRNA } \\
\text { (OD/50 islets) }\end{array}$} \\
\hline & & & & (ng/10 islets) & (ng insulin/ng DNA) & \\
\hline NOD & $\begin{array}{l}-(\text { Day } 0) \\
11(\text { Day } 7) \\
28(\text { Day } 7)\end{array}$ & $\begin{array}{l}- \\
91 \pm 2 \\
92 \pm 3\end{array}$ & $\begin{array}{l}855 \pm 139 \\
311 \pm 45^{\mathrm{a}} \\
291 \pm 26^{\mathrm{b}}\end{array}$ & $\begin{array}{l}991 \pm 61 \\
553 \pm 48^{c} \\
271 \pm 24^{c}\end{array}$ & $\begin{array}{l}1.46 \pm 0.30 \\
1.89 \pm 0.27 \\
0.96 \pm 0.07\end{array}$ & $\begin{array}{l}1.46 \pm 0.52 \\
2.01 \pm 0.46 \\
2.79 \pm 0.69\end{array}$ \\
\hline NMRI & $\begin{array}{l}-(\text { Day } 0) \\
11 \text { (Day } 7) \\
28(\text { Day } 7)\end{array}$ & $\begin{array}{c}- \\
93 \pm 3 \\
93 \pm 3\end{array}$ & $\begin{array}{l}394 \pm 49 \\
315 \pm 33 \\
343 \pm 26\end{array}$ & $\begin{array}{c}1074 \pm 87 \\
802 \pm 62^{\mathrm{a}} \\
273 \pm 40^{\mathrm{c}}\end{array}$ & $\begin{array}{l}2.40 \pm 0.15 \\
2.54 \pm 0.22 \\
0.75 \pm 0.08^{c}\end{array}$ & $\begin{array}{l}1.97 \pm 0.45 \\
2.06 \pm 0.38 \\
2.75 \pm 0.44\end{array}$ \\
\hline
\end{tabular}

Pancreatic islets were isolated from NOD or NMRI mice and studied immediately (day 0 ) or after 7 days in culture (day 7 ) at different glucose concentrations ( 11 or $28 \mathrm{mmol} / \mathrm{l}$ ). The recovery of islets on day 7 was expressed as the percentage of islets remaining in culture on day 7 as compared to day 0 . The insulin mRNA was determined by dot blot analysis, quantified through densitometry and expressed as optical density (OD, arbitrary units). The results are means \pm SEM of $8-11$ observations. ${ }^{a} p<0.05 ;{ }^{b} p<0.01 ;{ }^{\mathrm{c}} p<0.001$ when compared to the respective islet group on day 0

islets exposed to 11.1 or $28 \mathrm{mmol} / \mathrm{l}$ glucose for seven days revealed well preserved islets, with no obvious signs of cell necrosis or remaining mononuclear cells (not shown). In both NOD and NMRI islets, culture at $11.1 \mathrm{mmol} / \mathrm{l}$ glucose induced a decrease in insulin content, as compared to day 0 (Table 1 ). On the other hand, when the islet insulin content was expressed per DNA this difference was not evident. In both strains, culture at $28 \mathrm{mmol} / 1$ glucose induced a further decrease in insulin content, both as compared to day 0 and compared to islets cultured at $11.1 \mathrm{mmol} / \mathrm{l}$ glucose $(p<0.01$ or less). Correction of these results for DNA did not change the observed differences, except for a lack of significance when comparing NOD islets on day 0 and day seven. Immediately after isolation (day 0 ) islets obtained from NOD and NMRI mice had similar insulin mRNA content. After seven days in culture at $28 \mathrm{mmol} / \mathrm{l}$ glucose, both groups of islets tended to increase their insulin mRNA levels compared to the values observed in islets cultured at $11.1 \mathrm{mmol} / 1$ glucose, but these difference did not reach statistical significance (Table 1 ).

Culture at $28 \mathrm{mmol} / \mathrm{l}$ glucose, compared to $11.1 \mathrm{mmol} / 1$, increased the insulin accumulation in the medium of NMRI islets during the whole period of observation (Table 2). In contrast, in the cultures containing islets obtained from NOD mice there was no increase in the insulin accumulation in response to the high glucose concentration $(28 \mathrm{mmol} / \mathrm{l})$ during the first four days of culture, whereas an increase was observed during days five to six.

Islets obtained from the NOD mice showed a decreased insulin response to an acute glucose stimulation on day 0 (Table 3). However, after seven days in culture at both 11.1 and $28 \mathrm{mmol} / /$ glucose, there was a marked improvement in the insulin release in response to $16.7 \mathrm{mmol} / \mathrm{l}$ glucose. During the short-term incubation, islets previously cultured at $28 \mathrm{mmol} / 1$ glucose had a higher insulin release than islets cultured at $11.1 \mathrm{mmol} / 1$ glucose, both at $1.7(p<0.001)$ and $16.7 \mathrm{mmol} / \mathrm{l}$ glucose $(p<0.01)$. It is noteworthy that the basal insulin release at $1.7 \mathrm{mmol} / 1$ glucose was increased on day 0 , as compared to the basal insulin release of islets cultured at $11.1 \mathrm{mmol} / \mathrm{l}$ glucose.

In contrast to the observations made in the NOD islets, the NMRI islets showed a similar insulin release in re-
Table 2. Insulin accumulation in the medium of islets isolated from NOD or NMRI mice over a six-day period in culture at different glucose concentrations

\begin{tabular}{lllll}
\hline Mouse strain & $\begin{array}{l}\text { Medium } \\
\text { glucose } \\
(\text { mmol/h) }\end{array}$ & \multicolumn{2}{l}{$\begin{array}{l}\text { Insulin accumulation in the medium } \\
\left(\mathrm{ng} \cdot 10 \text { islets }^{-1} \cdot 48 \mathrm{~h}^{-1}\right)\end{array}$} \\
\cline { 3 - 5 } & Days 0-2 & Days 3-4 & Days 5-6 \\
\hline NOD & 11 & $255 \pm 38$ & $169 \pm 20$ & $131 \pm 12$ \\
& 28 & $264 \pm 35$ & $184 \pm 24$ & $192 \pm 24^{\mathrm{a}}$ \\
NMRI & 11 & $270 \pm 27$ & $173 \pm 22$ & $126 \pm 15$ \\
& 28 & $476 \pm 71^{\mathrm{c}}$ & $391 \pm 75^{\mathrm{c}}$ & $415 \pm 56^{\mathrm{b}}$ \\
\hline
\end{tabular}

The groups of islets were isolated and maintained in culture as described in Table 1. Medium was collected for insulin determination at 48 -h intervals. The results are means \pm SEM of 11-12 observations. ${ }^{\mathrm{a}} p<0.05 ;{ }^{\mathrm{b}} p<0.01 ;{ }^{\mathrm{c}} p<0.001$ when compared to the respective islet groups maintained at $11 \mathrm{mmol} / \mathrm{l}$ glucose

Table 3. Glucose-stimulated insulin release of islets isolated from NOD or NMRI mice and studied immediately or after seven days in culture at different glucose concentrations

\begin{tabular}{|c|c|c|c|}
\hline \multirow[t]{2}{*}{ Mouse strain } & \multirow{2}{*}{$\begin{array}{l}\text { Medium } \\
\text { glucose } \\
\text { (mmol/l) }\end{array}$} & \multicolumn{2}{|c|}{ Insulin release (ng $\cdot 10$ islets $^{-1} \cdot 60 \mathrm{~min}^{-1}$ ) } \\
\hline & & $\begin{array}{l}1 \mathrm{st} \text { h }(1.7 \mathrm{~mm} \omega / \mathrm{l} \\
\text { glucose })\end{array}$ & $\begin{array}{l}\text { 2nd h }(16.7 \mathrm{mmol} / 1 \\
\text { glucose })\end{array}$ \\
\hline NOD & $\begin{array}{l}-(\text { Day } 0) \\
11(\text { Day } 7) \\
28(\text { Day } 7)\end{array}$ & $\begin{array}{c}6.4 \pm 1.1 \\
1.4 \pm 0.2^{b} \\
11.6 \pm 1.2\end{array}$ & $\begin{array}{l}14.0 \pm 3.1 \\
53.5 \pm 8.2^{\mathrm{c}} \\
75.4 \pm 6.5^{\mathrm{c}}\end{array}$ \\
\hline NMRI (male) & $\begin{array}{l}-(\text { Day } 0) \\
11(\text { Day } 7) \\
28(\text { Day } 7)\end{array}$ & $\begin{array}{c}5.5 \pm 1.1 \\
1.4 \pm 0.1^{\mathrm{a}} \\
11.8 \pm 1.0^{\mathrm{b}}\end{array}$ & $\begin{array}{l}28.2 \pm 3.8 \\
34.2 \pm 4.9 \\
70.0 \pm 6.6^{c}\end{array}$ \\
\hline NMRI (female) & $\begin{array}{c}-(\text { Day 0) } \\
11(\text { Day } 7)\end{array}$ & $\begin{array}{l}7.4 \pm 2.3 \\
0.9 \pm 0.3^{a}\end{array}$ & $\begin{array}{l}25.2 \pm 4.5 \\
35.1 \pm 7.9\end{array}$ \\
\hline
\end{tabular}

The groups of islets were isolated and maintained in culture as described in Table 1. Islet insulin release experiments were performed by initially incubating the islets, in triplicate groups of seven, in $\mathrm{KRBH}$ containing $1.7 \mathrm{mmol} / \mathrm{h}$ glucose. After $60 \mathrm{~min}$ at $37^{\circ} \mathrm{C}$ $\left(\mathrm{O}_{2} / \mathrm{CO}_{2}, 95: 5\right)$ the medium was removed and the islets incubated for another $60 \mathrm{~min}$ in medium containing $16.7 \mathrm{mmol} / 1$ glucose. Values are given as means \pm SEM for $6-8$ observations. a $p<0.05$; ${ }^{b} p<0.01 ;{ }^{\mathrm{c}} p<0.001$ when compared to the respective islet group on day 0

sponse to $16.7 \mathrm{mmol} / \mathrm{l}$ glucose both on day 0 and after one week in culture at $11.1 \mathrm{mmol} / 1$ glucose. Culture at $28 \mathrm{mmol} / \mathrm{l}$ glucose induced an even higher insulin release in response to both 1.7 and $16.7 \mathrm{mmol} / \mathrm{l}$ glucose, as compared to NMRI islets immediately after isolation (day 0 ) 
or after one week in culture at $11.1 \mathrm{mmol} / \mathrm{l}$ glucose $(p<0.01)$.

In a separate series of experiments, the effects of culture in islets obtained from female NMRI mice were also studied. As observed in the male NMRI islets, these islets had a similar DNA content immediately after isolation and after seven days in culture at $11.1 \mathrm{mmol} / 1$ glucose (day 0,294 \pm 33 ; day 7,294 \pm 44 ng DNA/10 islets $[n=6]$ ). Furthermore, there was a similar insulin release in response to an acute stimulation with $16.7 \mathrm{mmol} / \mathrm{l}$ glucose both on days 0 and 7 (Table 3 ).

\section{Discussion}

Female NOD mice exhibit a long period of insulitis preceding the overt hyperglycaemia $[5,6]$. The female NOD mice in our colony have a severe insulitis at 12 13 weeks of age, and with increasing age there is a progressive glucose intolerance and deterioration of insulin release in response to glucose, but the mice are still able to maintain a normal basal glycaemia ([8], present data). Interestingly, when islets are removed from 12-13 week old NOD mice and maintained in culture for one week, there is a clear improvement in the insulin response to an acute glucose challenge ([8], present data). However, when islets are isolated from the non-diabetes prone NMRI mice, islet culture for seven days does not change the insulin response to glucose. These findings suggest that some factor(s) of the in vivo NOD mouse environment affects the insulin secretion of the islet Beta cells, and that this inhibition is reversible in vitro. Two possible explanations for the inhibition include a direct suppressive action by the immune system on the surviving islet cells $[21,22]$ or a potentially deleterious effect of increasing glycaemic levels $[3,4]$.

In order to test this second hypothesis, islets obtained from 12-13 week old female NOD mice were exposed to 11.1 or $28 \mathrm{mmol} / \mathrm{l}$ glucose over a period of seven days in culture. It can be argued that $11.1 \mathrm{mmol} / \mathrm{l}$ glucose is already a high glucose concentration. However, repeated studies have shown that in order to preserve an adequate insulin response to glucose in vitro it is necessary to maintain rodent islets at a slightly higher glucose concentration than that prevailing in vivo $[11,23,24]$. If increasing glucose levels in vivo cause a Beta-cell defective response to glucose [3], a deleterious functional effect of 11.1 and especially $28 \mathrm{mmol} / \mathrm{l}$ glucose in the NOD islets in vitro could be anticipated. Nevertheless, a period of seven days in culture at $28 \mathrm{mmol} / 1$ glucose neither increased the islet loss compared to $11.1 \mathrm{mmol} / 1$ glucose, nor decreased the islet DNA content, islet insulin mRNA content or the glucoseinduced insulin release. On the contrary, islets cultured at $28 \mathrm{mmol} / 1$ glucose released more insulin in response to a $16.7 \mathrm{mmol} / \mathrm{l}$ glucose stimulation than both freshly isolated NOD islets or NOD islets cultured at $11 \mathrm{mmol} / 1$ glucose. Interestingly, the acute insulin release in the presence of a low glucose concentration $(1.7 \mathrm{mmol} / \mathrm{l})$ was also increased in islets cultured at $28 \mathrm{mmol} / 1$ glucose. This finding has been reported previously [23, 25-27], and probably reflects the high glycogen contents in the islet cells [28], high levels of insulin mRNA and activated rates of insulin biosynthesis and release [29]. It is also noteworthy that the insulin content of NOD and NMRI islets decreased in culture, mainly at $28 \mathrm{mmol} / \mathrm{l}$ glucose. This decrease is probably related to a high functional activity in vitro, and reflects a depletion of insulin in the Beta cells rather than damage to these cells [30].

To further characterize the impact of islet isolation and culture on Beta-cell function, islets from NMRI mice were also studied. The use of islets from NMRI mice, a strain non-related to the NOD mice, was promoted by the difficulty in obtaining proper non-diabetic controls for the NOD mice. Indeed, the non-obese non-diabetic (NON) mice, a genetically related control for the NOD mice, present mild glucose intolerance and hypoinsulinaemia [31], precluding their use in the current series of experiments. Thus, it cannot be excluded that some of the apparent differences observed between the NOD and NMRI islets can be explained not only by the "prediabetic" condition of the NOD mice, but also by strain differences. In any case, the data obtained on the male and female NMRI islets suggest that culture of pancreatic islets in medium RPMI 1640 at $11.1 \mathrm{mmol} / \mathrm{l}$ glucose is, indeed, able to preserve a normal response to glucose stimulation. Thus, there was an identical insulin response to $16.7 \mathrm{mmol} / \mathrm{l}$ glucose on both days 0 and 7 . Similar findings have been recently reported for islets isolated from Sprague-Dawley rats and maintained under similar culture conditions [32]. However, it is conceivable that the collagenase treatment slightly damaged some Beta cells, as suggested by the increased insulin release at $1.7 \mathrm{mmol} / \mathrm{l}$ glucose on day 0 , and the increased insulin accumulation in the medium during the first two days of culture. It is also possible that leakage of insulin from non-viable Beta cells, in the first few hours following the islet isolation, can contribute to this finding.

Culture of NMRI islets in the presence of $28 \mathrm{mmol} / \mathrm{l}$ glucose potentiated the glucose-induced insulin release, as compared with both freshly isolated islets and islets cultured in the presence of $11 \mathrm{mmol} / \mathrm{lglucose}$. These findings confirm recent observations showing that culture for a 21 day period at $28 \mathrm{mmol} / \mathrm{l}$ glucose neither impairs the function of normal NMRI islets, nor potentiates the long-lasting damage induced by streptozotocin [27]. As a whole, the observations in islets obtained from NMRI and NOD mice tend to exclude the possibility that culture at high glucose concentrations is cytotoxic to both normal and immunologically assaulted mouse Beta cells. Furthermore, the results make hyperglycaemia, as a single factor, an unlikely explanation for the impaired insulin release observed in NOD islets in the "pre-diabetic" period, and reinforce the possibility of a direct suppressive effect of infiltrating mononuclear cells on the Beta cells. It remains to be determined which are the mediators of this suppression. The observation that the islet suppression can be improved in culture suggest a situation similar to that observed in rat [33] or mouse islets (Eizirik, unpublished data) following exposure to human interleukin-1 $1 \beta$, i.e., there is an impairment in islet function that can be reverted if the islets are cultured in a cytokine-free environment for seven days. 
It has been previously shown that intensive insulin treatment in the early stages of Type 1 diabetes mellitus can improve Beta-cell function [34-36], suggesting that the decrease in glucose levels could somehow protect the Beta cells. If high glucose is not directly deleterious to the islets, as suggested by the current in vitro data, how can these findings be explained? Recently it has been reported that culture of rat pancreatic islets at high glucose concentrations stimulates the expression of islet cell autoantigens, namely the $64,000-\mathrm{M}_{\mathrm{r}}$ protein [37]. Conversely, metabolic Beta-cell suppression in vivo reduces the expression of pancreatic monosialogangliosides, also considered a potential target for the autoimmune assault to the Beta cells [38]. If decreased metabolical demands decrease islet antigenic expression, the beneficial effects of intensive insulin therapy could be explained by a decrease in the immunological aggression to the islets. Indeed, exposure of rat islets to interleukin-1, one of the possible mediators of the autoimmune reaction in Type 1 diabetes, is able to induce a deficient insulin release in response to glucose, coupled to a better response to nonglucose secretagogues [22,33], similar to the response observed during the early stages of human Type 1 diabetes [2].

Acknowledgements. We thank Dr. M. Welsh for advice and help in the insulin mRNA determinations, Ms. I.-B.Hallgren, Ms. E. Forsbeck and Ms. A. Nordin for their excellent technical assistance and Ms. A. Snellman for careful typing of the manuscript. This work was supported by grants from the Juvenile Diabetes Foundation International, the Swedish Medical Research Council (12X-109; 12-8273; $12 \mathrm{X}-9237$ - connected to the " $\beta$-Cell Transplant, European Concerted Action for the Treatment of Diabetes"), the Swedish Diabetes Association, the Swedish Society of Medicine, the Nordic Insulin Fund, the Hoechst Diabetes Foundation, the Aage-Louis Hansens Mindefond, the Torsten and Ragnar Söderberg Foundation, the Magnus Bergvalls Stiftelse and the Family Ernfors Fund. D.L.E. is the recipient of a fellowship award from the Juvenile Diabetes Foundation International.

\section{References}

1. Eisenbarth GS (1986) Type 1 diabetes mellitus. A chronic autoimmune disease. N Engl J Med 314: 1360-1368

2. Ganda OP, Srikanta S, Brink SJ, Morris MA, Gleason RE, Soeldner IS, Eisenbarth GS (1984) Differential sensitivity to $\beta$-cell secretagogues in "early", type 1 diabetes mellitus. Diabetes 33 : $516-521$

3. Weir GC, Leahy JL, Bonner-Weir S (1986) Experimental reduction of B-cell mass: implications for the pathogenesis of diabetes. Diabetes Metab Rev 2: 125-161

4. Portha B, Blondel O, Serradas P, McEvoy RC, Giroix M-H, Kergoat M, Bailbe D (1989) The rat models of non-insulin dependent diabetes induced by neonatal streptozotocin. Diabete Metab 15: 61-75

5. Leiter EH, Prochazka M, Coleman D (1987) The non-obese diabetic (NOD) mouse. Am J Pathol 128:380-383

6. Lampeter EF, Signore A, Gale EAM, Pozzilli P (1989) Lessons from the NOD mouse for the pathogenesis and immunotherapy of human Type 1 (insulin-dependent) diabetes mellitus. Diabetologia 32: 703-708

7. Kano Y, Kanatsuma T, Nakamura N, Kitagawa Y, Mori H, Kajiyama S, Nakano K, Kondo M (1986) Defect of the first- phase insulin secretion to glucose stimulation in the perfused pancreas of the nonobese diabetic (NOD) mouse. Diabetes 35: $486-490$

8. Strandell E, Eizirik DL, Sandler S (1990) Reversal of $\beta$-cell suppression in vitro in pancreatic islets isolated from nonobese diabetic mice during the phase preceding insulin-dependent diabetes mellitus. J Clin Invest 85: 1994

9. Sandler S, Andersson A (1985) Modulation of streptozotocin-induced insulitis and hyperglycaemia in the mouse. Acta Pathol Microbiol Immunol Scand Sect [A] 93: 93-98

10. Howell SL, Taylor KW (1968) Potassium ions and the secretion of insulin by islets of Langerhans incubated in vitro. Biochem $J$ 108: $17-24$

11. Andersson A (1978) Isolated mouse pancreatic islets in culture: effects of serum and different culture media on the insulin production of the islets. Diabetologia 14: 397-404

12. Heding LG (1972) Determination of total serum insulin (IRI) in insulin-treated diabetic patients. Diabetologia 8:260-266

13. Krebs HA, Henseleit K (1932) Untersuchungen über die Harnstoffbildung im Tierkörper. Hoppe-Seylers Z Physiol Chem 210: 33-66

14. Kissane JM, Robins E (1958) The fluorometric measurement of deoxyribonucleic acid in animal tissues with special reference to the central nervous system. J Biol Chem 233: 184-188

15. Hinegardner RT (1971) An improved fluorometric assay for DNA. Anal Biochem 39: 197-201

16. Thomas PS (1980) Hybridization of denaturated RNA and small DNA fragments transferred to nitrocellulose. Proc Natl Acad Sci USA 77: 5201-5205

17. White BA, Bancroft FC (1982) Cytoplasmic dot hybridization. Simple analysis of relative mRNA levels in multiple small cell of tissue samples. J Biol Chem 257: 8569-8572

18. Eizirik DL, Sandler S, Welsh N, Hellerström C (1988) Preferential reduction of insulin production in mouse pancreatic islets maintained in culture after streptozotocin exposure. Endocrinology 122: $1242-1249$

19. Chan SJ, Noyes BE, Agarwal KL, Steiner DF (1979) Construction and selection of recombinant plasmids containing fulllength complementary DNAs corresponding to rat insulins I and II. Proc Natl Acad Sci USA 76: 5036-5040

20. Wallenstein S, Zucker CL, Fleiss JL (1980) Some statistical methods useful in circulation research. Circ Res 47:1-9

21. Eizirik DL, Sandler S (1989) Function and metabolism of pancreatic $\beta$-cells maintained in culture following experimentally induced damage. Pharmacol Toxicol 65: 163-168

22. Eizirik DL, Sandler S, Hallberg A, Bendtzen K, Sener A, Malaisse WJ (1989) Differential sensitivity to $\beta$-cell secretagogues in cultured rat pancreatic islets exposed to human interleukin- $1 \beta$. Endocrinology 125: 752-759

23. Eizirik DL, Strandell E, Sandler S (1988) Culture of mouse pancreatic islets in different glucose concentrations modifies B-cell sensitivity to streptozotocin. Diabetologia 31: 168-174

24. Giroix M-H, Serradas P, Portha B (1989) The desensitization of normal B-cells to glucose in vitro is transient and not related to high glucose levels. Endocrinology 125: 1999-2007

25. Sandler S, Andersson A (1987) Cryopreservation of mouse pancreatic islets: effects of different glucose concentrations in the post-thaw culture medium on islet recovery. Cryobiology 24: 285-391

26. Schnell Landström AH, Westman J, Borg H (1988) Lysosomes and pancreatic islet function. Time course of insulin biosynthesis, insulin secretion and lysosomal transformation after rapid changes in glucose concentration. Diabetes 37: 309-316

27. Eizirik DL, Sandler S (1989) Sustained exposure of toxically damaged mouse pancreatic islets to high glucose does not increase $\beta$-cell dysfunction. J Endocrinol 123: 47-51

28. Andersson A, Borglund E, Brolin SE (1974) Effects of glucose on the content of ATP and glycogen and the role of glucose phosphorylation of isolated pancreatic islets maintained in tissue culture. Biochem Biophys Res Commun 56: 1045-1051

29. Welsh M, Brunstedt J, Hellerström C (1986) Effect of D-glucose, 
L-leucine and 2-ketoisocaproate on insulin mRNA levels in mouse pancreatic islets. Diabetes 35: 228-231

30. Andersson A, Westman J, Hellerström C (1974) Effects of glucose on the ultra-structure and insulin biosynthesis of isolated mouse pancreatic islets maintained in tissue culture. Diabetologia 10: 743-753

31. Tochino Y (1986) Discovery and breeding of the NOD mouse. In: Tarui S, Tochino Y, Nonaka K (eds) Insulitis and Type 1 diabetes. Lessons from the NOD mouse. Academic, Tokyo Orlando San Diego New York, pp 3-10

32. Welsh N, Hellerström C (1990) In vitro restoration of insulin production in islets from adult rats treated neonatally with streptozotocin. Endocrinology 126: 1842-1848

33. Eizirik DL, Strandell E, Bendtzen K, Sandler S (1988) Functional characteristics of rat pancreatic islets maintained in culture following exposure to human interleukin 1. Diabetes 37: 916-919

34. Mirouze J, Selam JL, Pham TC, Mendoza E, Orsetti A (1978) Sustained insulin-induced remission of juvenile diabetes by means of an external artificial pancreas. Diabetologia 14: 223-227

35. Madsbad S, Krarup T, Faber OK, Binder C, Regeur L (1982) The transient effect of strict glycaemic control on $\mathrm{B}$-cell function in newly diagnosed Type 1 (insulin-dependent) diabetic patients. Diabetologia 22: 16-20

36. Shah S, Malone JI, Simpson NE (1989) A randomized trial of intensive insulin therapy in newly diagnosed insulin-dependent diabetes mellitus. N Engl J Med 320: 550-554

37. Kämpe O, Andersson A, Björk E, Hallberg A, Karlsson FA (1989) High-glucose stimulation of $64,000-\mathrm{M}_{\mathrm{r}}$ islet cell autoantigen expression. Diabetes 38: 1326-1328

38. Dotta F, Ziegler R, O'Neil JJ, Hayak RC, Eisenbarth GS, Appel MC (1989) Islet autoimmunity: identification and initial characterization of a metabolically regulable pancreatic ganglioside. Diabetologia 32: 438A

Received: 14 March 1990

and in final revised form: 13 July 1990

Dr. D. L. Eizirik

Department of Medical Cell Biology

Biomedicum, P.O. Box 571

S-751 23 Uppsala

Sweden 